\title{
Unexpected esophageal diseases appeared in thyroid resections
}

\author{
Liu Ye-huan, Lyu Shi-xu*', Zhou Yi-li, Wang Ou-chen and Zhang Xiao-hua
}

\begin{abstract}
Objective: In order to avoid the misdiagnosis of thyroid diseases, we need to discuss the clinical features and diagnostic methods of cervical esophageal cancer and Zenker's diverticulum.

Methods: The clinical and laboratory data of seven cases were reviewed retrospectively, and in all cases, esophageal-related diseases were misdiagnosed as thyroid diseases preoperatively. Among them, two cases were cervical esophageal cancer metastasized to thyroids but initially, they were misdiagnosed as thyroid cancer. The other five cases were Zenker's diverticulum, but were originally diagnosed as nodular goiter, and two out of the five cases were found with calcification. They were all detected by ultrasound examination without any clinical feature of esophageal diseases. Previous literatures only reported five cases of thyroid metastasis and three cases of Zenker's diverticulum.
\end{abstract}

Results: In both cases where cervical esophageal cancer metastasized to thyroid, anterior cervical neoplasm biopsy and surgical removal were performed followed by postoperative radiotherapy and chemotherapy. Both patients died from esophageal cancers in 7 and 15 months postoperatively. All five cases of Zenker's diverticulum received excision and repair without any postoperative complication or recurrence in the following 2 to 7 years.

Conclusions: Cervical esophageal cancer and Zenker's diverticulum may be misdiagnosed as thyroid disease. Careful and comprehensive diagnostic tests would be required to avoid misdiagnosis.

Keywords: Cervical esophageal cancer, Zenker's diverticulum, Thyroid misdiagnosis

\section{Background}

Thyroid diseases are commonly encountered endocrine disease in clinics. However, symptoms from other neck neoplasms such as esophageal diseases can mimic thyroid diseases sometimes and lead to misdiagnosis. With rising public awareness of primary prevention, neck ultrasound has been widely used as a routine project for thyroid abnormality [1]. About 3,000 cases of thyroid resection were performed in oncological surgery at our hospital every year. Among them, seven cases, collected from May 2006 to October 2014, were analyzed here, in which all esophageal-related diseases were misdiagnosed as thyroid diseases preoperatively.

\footnotetext{
* Correspondence: 1059647116@qq.com

Department of Oncology, The First Affiliated Hospital of Wenzhou Medical University, South of Bai-xiang Street, Ou-hai District, 325000 Wenzhou, Zhejiang, People's Republic of China
}

\section{Case presentation \\ Clinical data \\ Physical examination}

The neck neoplasms in all cases moved with swallowing, and they were medium-hard texture. No patients reported sensation of dysphagia or reflux, and no neck lymph node enlargement was appreciated. One of two patients with metastatic cervical esophageal cancer to the thyroid had obvious hoarseness, so did one patient with Zenker's diverticulum. The rest of Zenker's diverticulum all had anterior cervical pressure sensation.

\section{Laboratory examinations}

Thyroid hormone series and antibody were measured in seven cases. TSH, TT3, TT4, FT3, and FT4 were all in normal range. Only one case of esophageal diverticulum had mildly elevated TgAb concentration $(12.1 \mathrm{IU} / \mathrm{ml}$ with normal value approximately 0 to $4 \mathrm{IU} / \mathrm{ml}$ ) as shown in Table 1. Thyroid ultrasound (Figures 1 and 2) was 
Table 1 Physical and laboratory examinations

\begin{tabular}{|c|c|c|c|c|c|c|}
\hline Cases & Age (years)/sex & Esophageal disease & Symptoms & Size $(\mathrm{cm})$ & Location & $\begin{array}{l}\text { Thyroid hormone and } \\
\text { related antibody }\end{array}$ \\
\hline 1 & $54 / \mathrm{M}$ & Cervical esophageal cancer & No & $5 \times 2.3$ & Behind the right lobe & Normal \\
\hline 2 & $50 / \mathrm{M}$ & Cervical esophageal cancer & Hoarseness & $3.4 \times 2.5$ & Behind the right lobe & Normal \\
\hline 3 & $47 / F$ & Zenker diverticulum & Pressure sensation & $2.2 \times 4$ & Behind the left lobe & Normal \\
\hline 4 & $39 / F$ & Zenker diverticulum & Pressure sensation & $3.2 \times 3.6$ & Behind the left lobe & Normal \\
\hline 5 & $54 / \mathrm{M}$ & Zenker diverticulum & Pressure sensation & $1.8 \times 1$ & Behind the left lobe & Normal \\
\hline 6 & $35 / F$ & Zenker diverticulum & Pressure sensation & $4 \times 3.5$ & Behind the left lobe & Normal \\
\hline 7 & $37 / F$ & Zenker diverticulum & Hoarseness & $4 \times 4$ & Behind the left lobe & $\operatorname{TgAb} \uparrow$ \\
\hline
\end{tabular}

performed in all seven cases in which three cases accepted FNA, shown in Table 2. Total thyroidectomy with possible lymphadenectomy was originally planned for all seven cases. Display of surgery (Figure 3) amazed us. However, as intraoperative frozen biopsies (Figures 4 and 5) proved accurate by postoperative histopathological examinations in the following days altered the initial diagnosis, surgical plan was changed depending on the individual pathological result in each case after emergent thoracic surgery consultation. Details are in Table 3.

All the ultrasound descriptions were based on the preoperative records of the ultrasound examinations. ${ }^{a}$ Many thyroid follicular epithelial cells, several abnormal cells with intranuclear inclusions, sporadic polynuclear giant cells. ${ }^{b}$ Many thyroid follicular epithelial cells with bits of allotypic cells between focal areas of fibrous tissue. ${ }^{\mathrm{c}} \mathrm{No}$ obvious allotypic cells and sporadic inflammatory cells in pectin background.

\section{Follow-up data}

Both cases of metastatic cervical esophageal cancer to thyroid received nasal feeding for 1 week postoperatively, and no esophageal fistula occurred. Later, they accepted radiotherapy and chemotherapy according to the 2011 National Comprehensive Cancer Network (NCCN)

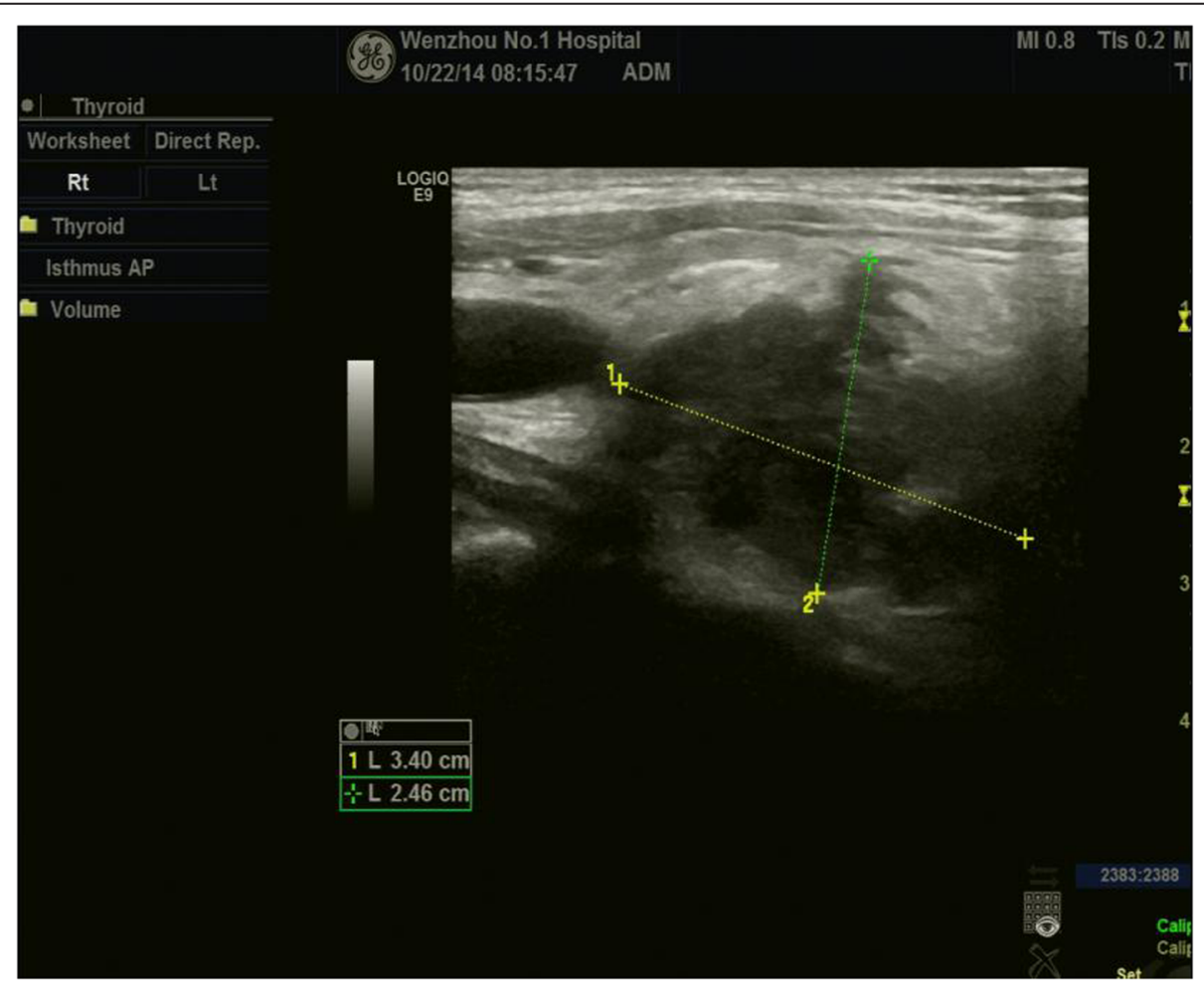

Figure 1 Ultrasound reexamination in a week before death showed a solitary, irregular, hypoechoic mass with some hyperechoic foci. Its border was unclear and the max diameter was $3.4 \mathrm{~cm}$. 


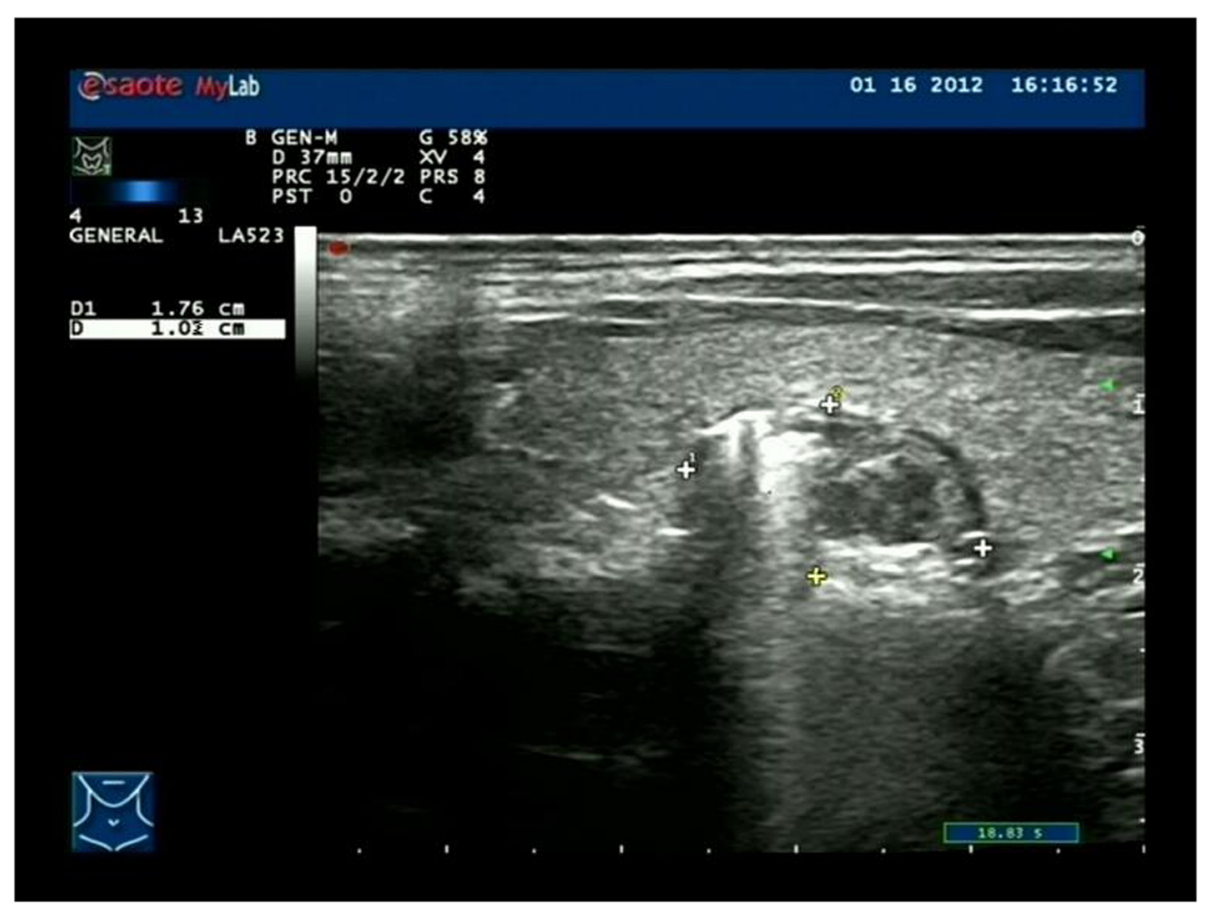

Figure 2 Ultrasound examination showed a solitary, irregular, hypoechoic of mass with post acoustic shadow. Its border was clear and smooth with a max diameter $1.8 \mathrm{~cm}$.

Esophageal Cancer Guidelines. They died from esophageal cancer in 7 and 15 months postoperatively. All five cases of Zenker's diverticulum had no postoperative complications or recurrence in the following 2 to 7 years and survived to the present.

\section{Discussion}

The incidence of metastatic spread of gastrointestinal malignancies to the thyroid gland is relatively low, and most of them are from the colo-rectum [2]. Thyroid metastasis originating from the esophagus is poorly documented. We conducted a review of current English

\section{Table 2 Ultrasound and FNA}

\begin{tabular}{llll}
\hline Cases & Ultrasound description & Misdiagnosis & FNA \\
\hline 1 & $\begin{array}{l}\text { Solitary, hypoechoic mass with } \\
\text { hyperechoic foci }\end{array}$ & $\begin{array}{l}\text { Thyroid nodule Tl- } \\
\text { RADS IVc }\end{array}$ & $+^{a}$ \\
2 & $\begin{array}{l}\text { Solitary, hypoechoic mass with } \\
\text { hyperechoic foci (Figure 1) }\end{array}$ & $\begin{array}{l}\text { Thyroid nodule Tl- } \\
\text { RADS IVb }\end{array}$ & \\
3 & Solitary, irregular hyperechoic area & Nodular goiter & No \\
4 & Solitary, complex hypoechoic mass & Nodular goiter & No \\
5 & $\begin{array}{l}\text { Solitary, hypoechoic of mass with } \\
\text { post acoustic shadow (Figure 2) }\end{array}$ & $\begin{array}{l}\text { Nodular goiter } \\
\text { with calcification }\end{array}$ & No \\
6 & Solitary, patchy hyperechoic mass & Nodular goiter & No \\
7 & Solitary, nodular calcification & Nodular goiter & $-{ }^{c}$ \\
& & with calcification & \\
\hline
\end{tabular}

literature related to such condition, and there have been a total of five cases reported previously [3-7]. Here, we presented two additional cases of thyroid metastasis from cervical esophageal cancer.

Table 4 summarized the clinical circumstances and ultrasound results from the five cases previously published plus our two cases of thyroid metastasis from cervical esophageal cancer. Among the seven patients, two patients were women and five were men. Their mean age was 55 years, with a range from 32 to 74 years. The majority of patients underwent thyroidectomy. The

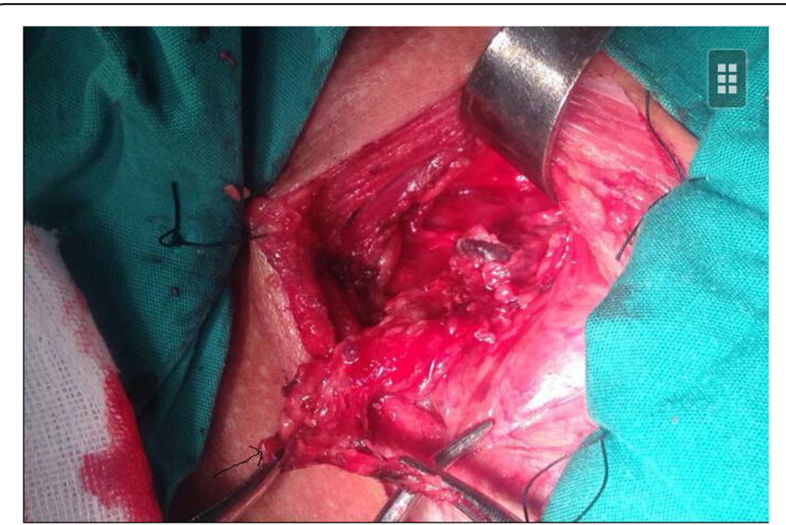

Figure 3 Neoplasm (arrowheads) attached to thyroid and invaded the right recurrent laryngeal nerve. 


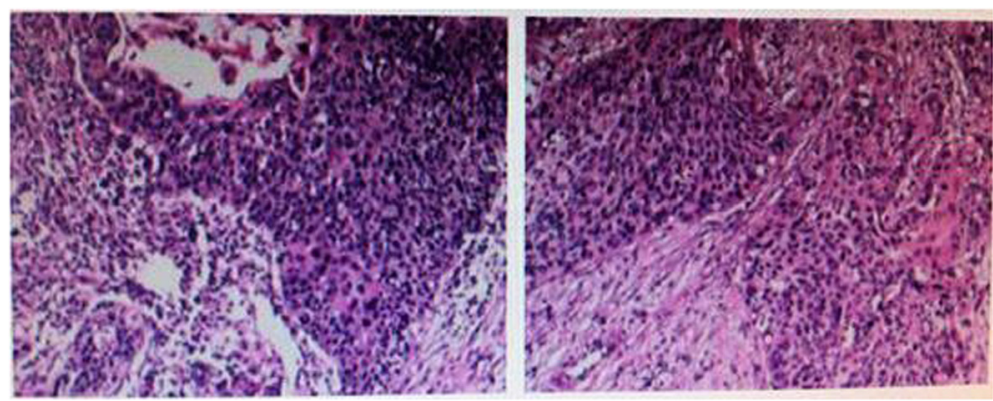

Figure 4 Pathological examination showed high differentiated squamous carcinoma.

postoperative histopathological examination all showed squamous cell carcinoma. Most of the patients with thyroid metastasis had a poor prognosis and died shortly after diagnosis. Details are in Table 4.

The incidence of Zenker's diverticulum mimic thyroid nodules is poorly documented. We conducted a review of the English and Chinese literature related to such condition and there were three published cases [8-10]. This article presents five additional case of Zenker's diverticulum mimic thyroid nodules.

Table 5 summarizes the clinical circumstances and ultrasound examination results for the three cases previously published plus our report of Zenker's diverticulum mimic thyroid nodules. Of the eight patients with Zenker's diverticulum, seven patients were women and one was a man. Their mean age was 49 years old, with a range of 35 to 73 years. Based on the above chief complaint, apart from some mild pressure sensation and foreign body sensation, all patients were asymptomatic and were not experiencing dysphagia, difficulty in swallowing, or reflux. Six patients underwent excision and repair and were recovered. Our patients are alive while there is no available follow-up data for the others. All the Zenker's diverticulum were located in the posterior aspect of the left thyroid lobe. Details are in Table 5.
A Zenker's diverticulum is a herniation of the mucosa and submucosa at Killian's triangle, a natural area of weakness at the junction of the thyropharyngeus and cricopharyngeus muscles in the posterior hypopharynx. It is believed that these diverticula are pulsion diverticula occurring as a result of spasm of the cricopharyngeus muscle, in coordination of the pharyngeal muscles or congenital muscle weakness. Due to the weak area is more obvious in the left side, Zenker's diverticula project to the left [11-16].

On ultrasonography, we can examine the sonographic similarities and differences between a Zenker's diverticulum versus a true thyroid abnormality as the following points. First, heterogeneous internal echo with strong echogenic foci caused by air bubbles or other particles could be regarded as micro calcifications of thyroid cancer, but there is stronger echogenicity and irregularity of the post acoustic shadow. Second is a hypo echoic rim with or without a multilayered pattern. This finding suggests that the digestive tract is the origin of the lesion (mucosa, submucosa, and muscular layers).Third is an irregular boundary of the posterior wall of the lesion at the posterior portion of the thyroid gland. Fourth are the chronological changes in the internal echo which are associated with changes in the contents of the diverticulum, such as air, water, or debris. These changes result
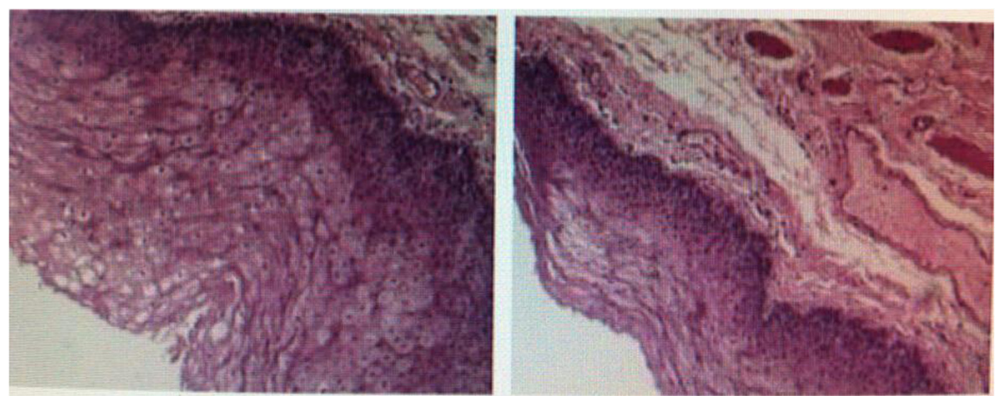

Figure 5 Pathological examination showed squamous epithelium with some small glands in lamina propria. 
Table 3 Intraoperative frozen biopsy and type of surgery

\begin{tabular}{|c|c|c|c|}
\hline Cases & Display of surgery & Intraoperative frozen biopsies & Type of surgery \\
\hline 1 & $\begin{array}{l}\text { Neoplasm adhered to thyroid to form a firm mass } \\
\text { which also enclosed the internal jugular vein. }\end{array}$ & Poorly differentiated squamous carcinoma & $\begin{array}{l}\text { Anterior cervical neoplasm } \\
\text { biopsy }^{\mathrm{a}}\end{array}$ \\
\hline 2 & $\begin{array}{l}\text { Neoplasm attached to thyroid and invaded the } \\
\text { right recurrent laryngeal nerve. (Figure 3) }\end{array}$ & $\begin{array}{l}\text { Highly differentiated squamous carcinoma } \\
\text { (Figure 4) }\end{array}$ & $\begin{array}{l}\text { Anterior cervical neoplasm } \\
\text { biopsy }^{\text {a }}\end{array}$ \\
\hline 3 & $\begin{array}{l}\text { Neoplasm was cystic with integrated envelope } \\
\text { and its central cavity communicated with esophagus. }\end{array}$ & Zenker's diverticulum ${ }^{\mathrm{b}}$ & Excision and repair \\
\hline 4 & $\begin{array}{l}\text { Neoplasm protruded from esophagus with } \\
\text { food remains in it. }\end{array}$ & Zenker's diverticulum ${ }^{c}$ & Excision and repair \\
\hline 5 & $\begin{array}{l}\text { Neoplasm can be touched from esophageal } \\
\text { outer membrane and the texture was soft. }\end{array}$ & Zenker's diverticulum ${ }^{d}$ (Figure 5) & Excision and repair \\
\hline 6 & $\begin{array}{l}\text { Neoplasm was pouch-like and communicated } \\
\text { with esophageal pyriform sinus. }\end{array}$ & Zenker's diverticulum ${ }^{e}$ & Excision and repair \\
\hline 7 & $\begin{array}{l}\text { Neoplasm compressed the left laryngeal recurrent } \\
\text { nerve. }\end{array}$ & Zenker's diverticulum $^{f}$ & Excision and repair \\
\hline
\end{tabular}

a Based on the consultations of thoracic surgeons and histopathological examinations, we performed the surgery and took a little of tissue sample for biopsy in order to avoid the esophageal fistula and unnecessary damage. Therefore, the majority of neoplasm is remaining and the size is similar with previous. ${ }^{\text {}}$ Squamous epithelium has hyperplasia with erosion and chronic inflammatory cells invade the lamina propria. Hemangiectasis is obvious. 'Squamous epithelial mucosa is chronically inflammatory and the base layer cracks have no cell and other ingredients in it. ${ }^{\mathrm{d}}$ The lining of cystic tissue wall is squamous epithelium with some small glands in lamina propria. ${ }^{\mathrm{e}}$ Mucosal surface concave into cavity with squamous epithelium as lining. ${ }^{\mathrm{f}}$ Squamous epithelial has significant hyperplasia.

during compression with a probe or during the swallowing of air or water [17-22].

According to our cases, some perspectives about misdiagnosis on esophageal diseases can be analyzed. First, they were all lacking of typical clinical symptoms such as dysphagia and reflux, so it is difficult to be detected in early stage at the most of the time $[23,24]$. Second, neoplasms moved by swallowing were all located closely in the posterior aspect of the thyroid gland and present as thyroid abnormality on ultrasonography. Third, because of the similar location, fine-needle aspiration inevitably brought out bits of thyroid cells so that it is too difficult to distinguish between primary and metastatic thyroid malignancies when highly anaplastic cells are observed microscopically [25]. Even though in our cases, we get the misleading FNA resulted by inadequate specimen, there are still studies to prove the false-negative rate of FNA is less than $1 \%$ and false-positive rate is only $1 \%$ to $3 \%$ in thyroid diagnosis [26-28]. In addition, according to the previous reports, FNA can improve the diagnosis of thyroid carcinoma and total diagnostic accuracy is $87.5 \%$, diagnostic accuracy of benign lesions is $93.8 \%$, and the diagnostic accuracy of malignancies is $97.3 \%$ in cervical masses [29-32].Besides, FNA is also fast, safe, and convenient which has been considered as a gold standard second to histopathological examinations.

Then, what should we do to avoid the misdiagnosis between esophageal and thyroid lesions? Take the

Table 4 Clinical circumstances and ultrasound examinations

\begin{tabular}{|c|c|c|c|c|c|c|}
\hline Source location & Age (years)/sex & Type of surgery (months) & Outcomes & Size $(\mathrm{cm})$ & Ultrasound & Description \\
\hline \multirow[t]{2}{*}{ Case 1} & $54 / \mathrm{M}$ & Anterior cervical & 7 & $5 \times 2.3$ & Solitary, hypoechoic mass & $\mathrm{R}$ \\
\hline & & Neoplasm biopsy & & & With hyperechoic foci & $\mathrm{R}$ \\
\hline \multirow[t]{2}{*}{ Case 2} & $50 / \mathrm{M}$ & Anterior cervical & 15 & $3.4 \times 2.5$ & Solitary, hypoechoic mass & \\
\hline & & Neoplasm biopsy & & & With hyperechoic foci & \\
\hline En-dong [3] & $61 / M$ & $\begin{array}{l}\text { Palliative bilateral NT+ } \\
\text { tracheostomy }\end{array}$ & 11 & $6.1 \times 3.9$ & $\begin{array}{l}\text { Solitary mass, heterogeneous, } \\
\text { hypoechoic }\end{array}$ & L \\
\hline $\begin{array}{l}\text { Shuangshoti S et al. } 1982 \\
\text { [4] }\end{array}$ & $58 / \mathrm{M}$ & $\Pi T+$ ipsilateral $C L$ & 5 & $1.5 \times 1.5$ & Solitary mass, NA & $\mathrm{R}$ \\
\hline Yamada T et al. 1999 [5] & $74 / F$ & $\mathrm{ST}+$ Bilateral $\mathrm{CL}$ & NA & NA & Widespread masses, calcified & $\begin{array}{l}\text { Not } \\
\text { specified }\end{array}$ \\
\hline Basu S et al. 2005 [6] & $55 / F$ & NA & NA & $6 \times 4$ & $\begin{array}{l}\text { Solitary mass, irregular, } \\
\text { hypoechoic }\end{array}$ & $\mathrm{R}$ \\
\hline $\begin{array}{l}\text { Cumbo-Nacheli G et al. } \\
2007 \text { [7] }\end{array}$ & $32 / \mathrm{M}$ & NA & NA & $2.5 \times 2.8$ & Solitary mass, NA & $\mathrm{R}$ \\
\hline
\end{tabular}

${ }^{\mathrm{a}}$ Follow-up since diagnosis of intra-thyroid metastases. NA, no data available; NT, near-total thyroidectomy; ST, subtotal thyroidectomy; $\mathrm{TT}$, total thyroidectomy; $\mathrm{CL}$, cervical lymphadenectomy. 
Table 5 Clinical circumstances and ultrasound examinations

\begin{tabular}{|c|c|c|c|c|c|c|}
\hline Source & Age (years)/sex & Chief complaint & Type of surgery & Size $(\mathrm{cm})$ & ultrasound description & Location \\
\hline Case 3 & $47 / F$ & Pressure sensation & Excision and repair & $2.2 \times 4$ & Solitary, irregular hyper echoic area & L \\
\hline Case 4 & $39 / F$ & Pressure sensation & Excision and repair & $3.2 \times 3.6$ & Solitary, substantial low echo & L \\
\hline Case 5 & $54 / \mathrm{M}$ & Pressure sensation & Excision and repair & $1.8 \times 1$ & $\begin{array}{l}\text { Solitary, low echo of mass with post } \\
\text { acoustic shadow }\end{array}$ & L \\
\hline Case 6 & $35 / F$ & Pressure sensation & Excision and repair & $4 \times 3.5$ & Solitary, hyper echoic foci & L \\
\hline Case 7 & $37 / F$ & Hoarseness & Excision and repair & $4 \times 4$ & Solitary, grit calcification & $\mathrm{L}$ \\
\hline Bin [8] & $50 / F$ & $\begin{array}{l}\text { Mild pharyngeal foreign } \\
\text { body sensation }\end{array}$ & No & $1.2 \times 0.6$ & Solitary, hypo echoic, calcified & L \\
\hline $\begin{array}{l}\text { Yong Fang et al. } \\
2011[9]\end{array}$ & $73 / F$ & Finding left neck mass & Excision and repair & $3 \times 1.8$ & Solitary, cystic and solid mass & $\mathrm{L}$ \\
\hline Beth-Ann [10] & $54 / F$ & Finding left neck mass & NA & $2 \times 1.2$ & Solitary, heterogeneous hypo echoic & L \\
\hline
\end{tabular}

NA, no data available.

medical histories and physical examinations carefully and especially pay attention to the special clinical symptoms of esophageal diseases such as dysphasia or reflux $[12,16]$.According to the 2010 National Comprehensive Cancer Network (NCCN) Thyroid Carcinoma Guidelines, measuring TSH and accepting the ultrasonography were considered as routine projects in thyroid diseases. To the suspected thyroid malignancies after ultrasonography, FNA is often recommended. In order to improve the diagnostic accuracy, we can puncture and smear more to get satisfactory specimens. When it illustrates that sonographic left-sided thyroid nodules that exhibit squamous cells, bacteria, or foreign material on FNA biopsy, we should raise the suspicion of an occult Zenker's diverticulum. What is more, X-ray barium meal examination, endoscopy, ECT, CT, MRI, and CNB could be applied to help to make the correct diagnosis if necessary [33-41].

\section{Conclusions}

Cervical esophageal cancer and Zenker's diverticulum may be misdiagnosed as thyroid diseases. Careful and comprehensive diagnostic tests would be required to avoid misdiagnosis.

\section{Consent}

Written informed consent was obtained from the patients for publication of this case report and any accompanying images. A copy of the written consent is available for review by the Editor-in-Chief of this journal.

\section{Abbreviations}

TSH: thyroid stimulating hormone; FNA: fine-needle aspiration; ECT: emission computed tomography; CT: computed tomography; MRI: magnetic resonance imaging; CNB: core needle biopsy.

\section{Competing interests}

The authors declare that they have no competing interests.

\section{Authors' contributions}

LYH carried out the initial conception and design as well as collection of data and clinical records of the patient. LSX participated in its design and helped to edit the manuscript. ZYL help to revise the manuscript. WOC and $\mathrm{ZXH}$ made up the surgical team involved in the most of patients. All authors read and approved the final manuscript.

\section{Authors' information}

Liu Ye-huan is a graduate of Wenzhou Medical University, Wenzhou, Zhejiang, People's Republic of China. Lyu Shi-xu is a surgeon of Department of Oncology, The First Affiliated Hospital of Wenzhou Medical University, Wenzhou, Zhejiang, People's Republic of China. Zhou Yi-li is a surgeon of Department of Oncology, The First Affiliated Hospital of Wenzhou Medical University, Wenzhou, Zhejiang, People's Republic of China. Wang Ou-chen is Chief Physician of Department of Oncology, The First Affiliated Hospital of Wenzhou Medical University, Wenzhou, Zhejiang, People's Republic of China. Zhang Xiao-hua is Chief Physician of Department of Oncology, The First Affiliated Hospital of Wenzhou Medical University, Wenzhou, Zhejiang, and People's Republic of China.

\section{Acknowledgements}

We thank all of the pathologists at the First Affiliated Hospital of Wenzhou Medical University for their assistance with the pathologic analysis. Without their efforts, this article would not be possible. This work was supported by Zhejiang Province Natural Science Foundations (NO.LY13H160034 and NO. Y207526).

Received: 7 December 2014 Accepted: 7 March 2015

Published online: 30 March 2015

\section{References}

1. Gray SL, O'Neill G, McGarry G. The predictive value of structured ultrasonographic staging for thyroid nodules. J Laryngol Otol. 2014;128(10):914-21.

2. Yoshida A, Imamura A, Tanaka H, Hirano M, Kamma H, Ueno E, et al. A case of metastasis from gastric cancer to the thyroid gland. Jpn J Surg. 1989:19:480-4

3. Chen E, Cheng P, Yan X, Ye Y, Chen C, Ji X, et al. Metastasis of distal esophageal carcinoma to the thyroid with presentation simulating primary thyroid carcinoma: a case report and review of the literature. World I Surg Oncol. 2014;12(1):106.

4. Shuangshoti S. Primary carcinomas of esophagus and bronchus with presentation simulating primary carcinoma of thyroid gland. J Med Assoc Thai. 1982;65:38-44.

5. Yamada T, Tatsuzawa Y, Yagi S, Fujioka S, Kitagawa S, Nakagawa M, et al. Lymphoepithelioma-like esophageal carcinoma: report of a case. Surg Today. 1999;29:542-4.

6. Basu S, Nair N, Borges AM. Squamous cell carcinoma of esophagus masquerading as solitary thyroid nodule. Indian J Cancer. 2005;42:205-7. 
7. Cumbo-Nacheli G, De Sanctis JT, Chung MH. Proximal esophageal adenocarcinoma presenting as a thyroid mass: case report and review of the literature. Thyroid. 2007;17:267-9.

8. Li B, Zheng XY, Feng LZ. Zenker diverticulum misdiagnosed as thyroid nodule 1 case on ultrasonography. J Otolaryngol Head Neck Surg. 2012;47(009):770-1.

9. Fang Y, Guo YY, Wang YY. Zenker's diverticulum misdiagnosed as thyroid nodule in 1 case analysis. China J Misdiagnosis. 2012;11(34):8387-7.

10. Shanker BA, Davidov T, Young J, Chang El, Trooskin SZ. Zenker's diverticulum presenting as a thyroid nodule. Thyroid. 2010;20(4):439-40.

11. Veenker $E$, Cohen Jl. Current trends in management of Zenker diverticulum. Curr Opin Otolaryngol Head Neck Surg. 2003:11(3):160-5.

12. Yazaki E, Woodland P, Sifrim D. Uses of esophageal function testing: dysphagia. Gastrointest Endosc Clin N Am. 2014;24(4):643-54.

13. Bagheri R, Maddah G, Mashhadi MR, Haghi SZ, Tavassoli A, Ghamari MJ, et al. Esophageal diverticula: analysis of 25 cases. Asian Cardiovasc Thorac Ann. 2013;22:0218492313515251.

14. Bock JM, Petronovich JJ, Blumin JH. Massive Zenker diverticulum. Ear Nose Throat J. 2012:91(8):319-20.

15. Skrobic OM, Simic AP, Radovanovic NS, Spica BV, Pesko PM. Current concepts in the anatomy and origin of pharyngeal diverticula. Acta Chir lugosl. 2009;56(1):17-24.

16. Ferreira L, Simmons DT, Baron TH. Zenker's diverticula: pathophysiology, clinical presentation, and flexible endoscopic management. Dis Esophagus. 2008;21(1):1-8

17. Biggi E, Derchi LE, Cicio GR, Neumaier CE. Sonographic findings of Zenker's diverticulum. J Clin Ultrasound. 1982;10:395-6.

18. Hayashi N, Tamaki N, Konishi J, Endo K, Misaki T, Torizuka K, et al. Lateral pharyngoesophageal diverticulum simulating thyroid adenoma on sonography. J Clin Ultrasound. 1984;12:592-4.

19. Komatsu M, Komatsu T, Inove K. Ultrasonography of Zenker's diverticulum: special reference to differential diagnosis from thyroid nodules. Eur J Ultrasound. 2000;11:123-5.

20. Yahara T, Machi J. Image of the month: Zenker diverticulum. Arch Surg. 2002;137:619-20.

21. Kwak JY, Kim EK. Sonographic findings of Zenker diverticula. J Ultrasound Med. 2006;25:639-42.

22. Lixin J, Bing $H$, Zhigang W, Binghui Z. Sonographic diagnosis features of Zenker diverticulum. Eur J Radiol. 2011;80(2):e13-9.

23. Hong SJ, Kim TJ, Nam KB, Lee IS, Yang HC, Cho S, et al. New TNM staging system for esophageal cancer: what chest radiologists need to know. RadioGraphics. 2014;34(6):1722-40.

24. Myers EN, Suen JY, Myers JN, Hannah EYN. Cancer of the head and neck. Philadelphia (PA). 2003;7:5-16.

25. Nakhjavani MK, Gharib H, Goellner JR, Van Heerden JA. Metastasis to the thyroid gland. A report of 43 cases. Cancer. 1997:79:574-8.

26. Orell S, Sterret G, Whitaker D, Walters M. Chapter 6. Thyroid. UK: Elsevier Churchill Livingstone; 2005. p. 125-63.

27. Ali SZ, Cibas ES. The Bethesda system for reporting thyroid cytopathology: definitions, criteria and explanatory notes. New York: Springer; 2010. p. 1-166.

28. Cibas ES, Ducatman BS. Cibas ES. Chapter 9. Thyroid. Philadelphia: Saunders; 2009. p. 255-84.

29. Gu YH, Liu Y, Peng CY, Zhou CJ. Significance of fine-needle aspiration cytology in cervical masses. China J Mod Med. 2009;19(006):0915-5.

30. Williams BA, Bullock MJ, Trites JR, Taylor SM, Hart RD. Rates of thyroid malignancy by FNA diagnostic category. J Otolaryngol Head Neck Surg. 2013;42(1):61.

31. Tatomirovic Z, Skuletic V, Bokun R, Trimcev J, Radic O, Cerovic S, et al. Fine needle aspiration cytology in the diagnosis of head and neck masses: accuracy and diagnostic problems. J BUON. 2008:14(4):653-9.

32. Kaur A, Chew CT, Lim-Tan SK. Fine needle aspiration of 123 head and neck masses - an initial experience. Ann Acad Med Singapore. 1993:22(3):303-6.

33. Chan RCL, Chan YW. PET/CT is complementary to fine-needle aspiration cytology in assessment of irradiated neck in head and neck cancers. Surgery Research and Practice. 2014;2014:191267.

34. Liu Y, Tao X, Shi H, Li K. MRI findings of solitary fibrous tumours in the head and neck region. Dentomaxillofacial Radiology. 2014;43(3).

35. Lü Y, Liu M, Li C, Wu L, Fritz J. MRI-guided biopsy and aspiration in the head and neck: evaluation of 77 patients. Eur Radiol. 2012:22(2):404-10.
36. Hashiba K, de Paula AL, da Silva JGN, Cappellanes CA, Moribe D, Castillo CF, et al. Endoscopic treatment of Zenker's diverticulum. Gastrointest Endosc. 1999;49(1):93-7.

37. Wang $C H$, Lee YC, Wang CP, Chen CC, Ko JY, Han ML, et al. Use of transnasal endoscopy for screening of esophageal squamous cell carcinoma in high-risk patients: yield rate, completion rate, and safety. Dig Endosc. 2014;26(1):24-31.

38. Nagai $\mathrm{K}$, Ishihara $\mathrm{R}$, Ishiguro $\mathrm{S}$, Ohta $\mathrm{K}$, Kanzaki $\mathrm{H}$, Yamashima $\mathrm{K}$, et al. Endoscopic optical diagnosis provides high diagnostic accuracy of esophageal squamous cell carcinoma. BMC Gastroenterol. 2014;14(1):141.

39. Elvin A. Ultrasound-guided $1.2 \mathrm{~mm}$ cutting needle biopsies of head and neck tumors. Acta Radiol. 1997;38(3):376.

40. Pfeiffer J, Kayser G, Technau-Ihling K, Boedeker CC, Ridder GJ. Ultrasoundguided core-needle biopsy in the diagnosis of head and neck masses: indications, technique, and results. Head \& Neck. 2007;29(11):1033-40.

41. Case DJ, Baron TH. Flexible endoscopic management of Zenker diverticulum: the Mayo Clinic experience. Mayo Clinic Proceedings. Elsevier. 2010;85(8):719-22

\section{Submit your next manuscript to BioMed Central and take full advantage of:}

- Convenient online submission

- Thorough peer review

- No space constraints or color figure charges

- Immediate publication on acceptance

- Inclusion in PubMed, CAS, Scopus and Google Scholar

- Research which is freely available for redistribution 